\title{
PENAMAAN “LUM" PADA KELOMPOK MASYARAKAT DINAMISME DI BANGKA BAGIAN UTARA: SEBUAH TINJAUAN SEMANTIK PRAGMATIK
}

\author{
Asrul Munazar \\ Jurusan Sastra Inggris, Fakultas Ilmu Sosial dan Ilmu Politik
}

\begin{abstract}
A proper name is not only an identity for people or things around but also organization and community. The Processes behind naming are presented and explained in various ways to give the new insight of creating a name. This research deals with the lexicon of lum for naming used on groups of dynamism community. To explore the nature of lexical meaning, qualitative method was used in this research with descriptive approach. As an adverb class in Bangka language daily spoken, the lexicon was analysed by semantic pragmatics perspective to investigate the meaning of its name. The result showed that the lexicon of lum becomes a name for dinamism community as "lum tribe" originally has conotation meaning and increases missunderstanding problems among the community in Belinyu.
\end{abstract}

Keywords : naming, qualitative method, lexicon lum, semantic pragmatics

\section{A. PENDAHULUAN}

\section{A.1 Latar Belakang}

Banyak tulisan - tulisan ilmiah maupun popular bahkan sebuah website kebudayaan, mengulas tentang orang - orang atau kelompok masyarakat yang belum memiliki keyakinan pada satu dari enam agama resmi dengan menyebutkan nama "suku lum" pada mereka. Kelompok masyarakat dinamisme tersebut adalah orang orang yang hidup dan tinggal di wilayah Bangka Bagian utara yang tersebar di beberapa dusun seperti ; orang Air Abik di dusun Air Abik, desa Gunung Muda kecamatan Belinyu, Orang Mapur di desa Mapur kecamatan Riau Silip serta orang Pejem di desa Pejem Kecamatan Belinyu.

Banyak yang belum menyadari bahwa nama memiliki peranan penting dalam kehidupan manusia karena nama memiliki keterkaitan dengan benda yang dirujuk. Penamaan suatu benda atau nama diri (proper name) adalah merupakan nomina yang merujuk pada satu entitas tertentu (Bach: 2002). Setiap benda tentu saja memiliki nama sebagai indentitas. Penamaan benda -benda terkadang didasarkan pada kecocokan objek dengan deskripsi "nalar/perasaan" yang timbul karena saling berasosiasi.

Nama diri diberikan tidak hanya terbatas pada benda - benda seperti hewan, tumbuhan, nama orang, nama benda disekitar tetapi juga pada kelompok -kelompok seperti organisasi, kelompok masyarakat, kota, negara dan sebagainya. Hal tersebut dilakukan untuk membedakan antar satu dengan lainnya.

Penamaan suatu benda tidak terlepas dari keadaan atau cermin dari individu, cermin dari sebuah komunitas, cermin segala aspek kehidupan 
(Jendra: 2000). Proses penamaan diri tidak saja merupakan cerminan dari individu atau kelompok saja, akan tetapi juga merupakan persepsi persepsi. Nama diri yang diberikan pada suatu individu atau kelompok dapat saja memiliki makna konotatif dan denotatif, penyandang nama-nama seperti David, James John, Joseph, Michael, Paul, Richard, Robert, dan Thomas dipandang lebih kuat dan lebih aktif daripada penyandang nama-nama Bernard, Dale, Edmond, Ivan, Reymond, dan Stanley (Mulyana: 2005).

Nama diri yang bersifat konotasi negatif tidak saja sebatas pada nama nama manusia tetapi juga pada nama - nama suatu kelompok maupun suatu organisasi. Oleh karena itu, penamaan "lum" pada orang - orang Mapur akan dikaji menurut kajian semantik pragmatik guna menghindari penamaan yang bermakna konotasi negatif pada suatu kelompok masyarakat.

\section{A.2 Masalah Penelitian}

Masalah di dalam penelitian ini adalah :

a. Bagaimana deskripsi makna leksikal "lum" berdasarkan tataran semantik pragmatik pada bahasa Bangka dialek Belinyu Kota?

b. Bagaimana sejarah penamaan lum pada orang Mapur berdasarkan makna linguistik dan penggunaan (semantik pragmatik)?

\section{A.3 Tujuan Penelitian}

Adapun tujuan penelitian ini adalah:

1. memaparkan makna leksikal lum yang sebenarnya berdasarkan tataran semantik pragmatik.

2. memaparkan sejarah penamaan lum pada orang Mapur dan menentukan konotasi penamaan tersebut.

\section{A.3 Tinjauan Pustaka \\ A.3.1 Nama Diri (Proper Noun)}

Pembahasan mengenai nama diri banyak dibahas dalam bidang filsafat dan Linguistik, terutama semantik, untuk mengkaji apakah nama - nama yang menjadi pembahasan tersebut memiliki makna ataukah tidak. Para linguis sepakat bahwa nama diri yang tidak memiliki makna tetapi hanya berfungsi sebagai suatu identitas yang bermakna denotatif disebut sebagai nama tidak aktif (Anderson: 2007).

Quirk (1985) mengungkapkan bahwa dalam kajian tatabahasa, nama diri (proper noun) dikategorikan dalam kelas nomina (noun) terutama kategori nomina milik khusus (proper noun) yang berbeda dengan subkategori nomina umum (common noun). Nomina milik khusus, menurut Quirk, mengacu pada nomina-nomina yang dikategorikan sebagai nama. Termasuk dalam salah satu subkategorinya adalah nama diri.

Sementara itu, nomina umum mengacu pada nomina yang mencakup nama benda-benda pada umumnya (common noun). Berdasarkan hal tersebut, dapat diketahui bahwa meskipun sama-nama dikategorikan nomina dan nama, leksikon Kota dengan Jakarta (nama sebuah kota) adalah dua kata yang berada pada sekalipun sama-nama merupakan nomina dan nama, leksikon kota dengan Jakarta (nama sebuah kota) adalah dua kata yang berada pada subkategori nomina yang berbeda. Dalam hal ini leksikon kota masuk ke dalam subkategori nomina umum dan leksiko Jakarta, yang merupakan nama diri sebuah kota, masuk ke dalam subkategori nomina milik khusus.

Crystal (1987) menyatakan bahwa studi tentang nama-nama diri (proper names) disebut Onomastikatau Onomatologi. Studi tersebut menurutnya mempunyai cabang-cabang, yaitu Antroponomastik, yang fokus kajiannya adalah masalah nama-nama orang (personal names) dan 
Toponomastik (Toponomastics) yang memfokuskan kajiannya pada masalah nama-nama tempat. Menurut Crystal,dalam menelusuri objek studinya Onomastik dapat memanfaatkan sudut pandang dari bidang keilmuan yang berbeda-beda, seperti bidang linguistik, filsafat, sosiologi, dan antropologi. Crystal (1987) juga mengungkapkan bahwa untuk menyebut studi ilmiah tentang nama-nama diri (personal names), kini istilah Onomastik lebih sering digunakan untuk menggantikan istilah Antroponomastik. Sedangkan, istilah toponomastik tetap digunakan untuk menyebut studi tentang nama-nama tempat.

Danesi (2004) mengungkapkan bahwa nama adalah nomina yang khusus. Menurut Danesi, nama menjadi objek kajian yang menarik karena adanya keterkaitan nama dengan budaya masyarakat tempat hidup si pemilik nama seperti halnya Almos dkk.(2009) yang juga mengungkapkan bahwa penamaan seseorang atau komunitas memiliki dua hal yaitu termotivasi dan tak termotivasi.

Selain nama diri untuk orang, penamaan terhadap suatu kelompok atau organisasi juga terjadi sama halnya seperti memberikan nama -nama pada orang. Hanya saja, nama diri suatu kelompok atau organisasi lebih bersifat nama - nama tempat, nama - nama pemilik, nama - nama karakter maupun nama -nama yang menjadi ciri khas kelompok atau organisasi tersebut.

Pemberian nama kelompok atau organisasi biasanya bersifat denotatif, yaitu bersifat wajar dan diterima. Akan tetapi, terkadang pemberian nama diri untuk suatu kelompok atau organisasi dapat saja bersifat konotatif, yang memiliki persepsi - persepsi kurang dapat diterima dan tidak wajar. Pemberian nama yang bersifat konotatif dapat terjadi karena dua hal; disadari dan tidak disadari. Disadari maksudnya adalah baik anggota suatu organisasi atau kelompok maupun bukan anggota organisasi atau kelompok tersebut menyadari bahwa dominasi sebagian besar karakter anggota kelompok atau organisasi tersebut mengarah pada satu karakter yang sama walaupun tidak seluruh anggota suatu kelompok atau organisasi mencerminkan kelompok atau organisasi tersebut.

Penamaan nama yang konotatif pada suatu organisasi atau kelompok contohnya pada frasa serikat buruh. Leksikon Buruh merupakan kategori nomina umum yang memiliki makna konotasi negatif, pemakaian kata buruh dianggap kasar, kurang tepat serta tidak mewakili golongan atau tingkatan para pekerja, oleh karena itu, leksikon pekerja dianggap lebih tepat dan lebih mewakili daripada buruh walaupun bersinonim (KBBI : 2012).

Penamaan nama yang bersifat konotatif tak disadari maksudnya adalah penamaan yang tidak disadari oleh anggota suatu organisasi atau kelompok tetapi disadari oleh bukan anggota organisasi atau kelompok tersebut. Penamaan untuk kategori tak disadari biasanya diberikan oleh bukan anggota suatu organisasi atau kelompok karena dominasi karakter anggota kelompok atau organisasi tersebut memiliki ciri khas yang dipersepsikan konotatif. Contohnya : gerombolan teroris. Leksikon gerombolan merupakan nomina umum yang bersifat konotatif daripada leksikon rombongan walaupun kedua leksikon tersebut bersinonim (KBBI : 2012).

\section{A.3.2 Perpaduan Semantik Pragmatik (Se- mantics Pragmatics Interfaces)}

makna linguistik (bahasa) berbeda dengan makna penggunaan. Semantik dan pragmatik adalah cabang ilmu bahasa yang sama-sama menelaah makna-makna satuan lingual. Hanya saja, semantik mempelajari makna linguistik atau makna bersifat internal, sedangan pragmatik mempe- 
lajari makna penutur atau makna dalam penutur dan bersifat eksternal yang berhubungan dengan konteks. Dengan kata lain, semantik mempelajari arti harfiah dari sebuah, ide sedangkan pragmatik adalah makna tersirat dari ide yang diberikan.

Bila diamati lebih jauh, makna yang menjadi kajian dalam semantik adalah makna linguistik (linguistics meaning) atau makna semantik (semantic sense), sedangkan yang dikaji oleh pragmatik adalah maksud penutur (speaker meaning atau speaker sense) (verhaar, 1977; Parker:1986). Semantik adalah telaah makna kalimat sedangkan pragmatik adalah telaah makna tuturan. Semantik adalah ilmu linguistik yang mempelajari makna yang terkandung di dalam morfem, kata, frasa, dan kalimat yang bebas konteks. Makna linguistik di sini adalah makna yang terdapat di dalam bahasa, yang distrukturkan di dalam dan oleh sistem bahasa, yang dipahami lebih kurang sama oleh para penutur dalam kegiatan berkomunikasi secara umum dan wajar (Subroto :1999).

Di dalam pragmatik, maksud penutur yaitu makna (sense), berhubungan erat dengan suatu system yang kompleks dari elemen linguistik, yaitu kata-kata. makna menitikberatkan pada makna kalimat dan hubungannya dengan makna kata (Palmer: 1981). Sehingga dapat dikatakan bahwa maksud penutur di sini tidak terlepas dari konteks kalimat, apa yang dimaksud penutur belum tentu sama dengan yang dimaksud oleh lawan tutur. Dalam pragmatik jika dalam pemakaiannya terjadi kesalahan pemakaian tatabahasa yang disengaja oleh penutur, maka dikatakan bahwa terdapat maksim tindak tutur yang dilanggar. Sementara itu, semantik tidak menganalisis bahasa dari sisi pemakaiannya sehingga jika terjadi kesalahan penutur yang disengaja, semantik tidak dapat menentukan makna asli dari penutur tersebut karena hanya didasarkan atas makna secara umum.

\section{Contoh:}

Dalam kalimat berikut, B menjawab pertanyaan A dengan setidaknya tiga kemungkinan cara untuk menyatakan "belum" atau "tidak ingin".

A : Siang ini kamu sudah makan?

Respon dapat saja seperti dibawah ini :

$\mathrm{B}(1)$ : saya belum makan. Tapi saya tidak in gin makan.

B (2) : saya sudah makan barusan.

B(2) : saya masih kenyang, kok.

Untuk mengatakan maksudnya, B setidaknya dapat mengutarakan dengan tiga tuturan: B(1) secara langsung menyatakan maksud dan alasannya; $\mathrm{B}(2)$ dengan berbohong, secara tidak langsung ia menyatakan tidak ingin makan; $\mathrm{B}(3)$ demi alasan kesopanan, dan secara tidak langsung juga, mengimplikasikan ia tidak ingin makan. Untuk menjawab pertanyaan A, meskipun juga tidak dapat menjelaskan dengan sangat tepat, semantik hanya dapat menganalisis meaning dengan jelas pada kalimat B(1) karena kalimat tersebut secara langsung menjawab pertanyaan A, namun semantik tidak dapat menjelaskan secara tepat arti dari $\mathrm{B}(2)$ dan $\mathrm{B}(3)$ karena $\mathrm{B}$ menjawabnya secara tidak langsung sehingga memerlukan pemahaman terhadap situasi di sekitarnya.

\section{A.3.3 Deskripsi Semantik}

Kempson (dalam Aarts dan Calbert:1979) berpendapat, ada empat syarat yang harus dipenuhi untuk mendeskripsikan semantik. Keempat syarat itu adalah:

1. Teori itu harus dapat meramalkan makna setiap satuan yang muncul yang didasarkan pada satuan leksikal yang membentuk kalimat.

2. Teori itu harus merupakan seperangkat kaidah. 
3. Tori itu harus membedakan kalimat yang secara gramatikal benar dan yangt tidak dilihat dari segi semantik.

4. Teori tersebut dapat meramalkan makna yang berhubungan dengan antonym, kontradiksi, sinonim. Dalam kaitannya dengan semiotik, Morris (dalam Levinson: 1983) mengemukakan tiga subbagian yang perlu dikaji, yakni :

(i) Sintaksis (syntactic) yang mempelajari hubungan formal antara tanda dengan tanda yang lain

(ii) Semantik (semantics), yakni studi tentang hubungan tanda dengan objek,

(iii) Pragmatik (pragmatics), yakni studi tentang hubungan tanda dalam pemakaian. Manusia berkomunikasi melalui kalimat. Kalimat yang berunsurkan kata dan unsur suprasegmental dibebani unsur yang disebut makna, baik makna gramatikal maupun makna leksikal, yang semuanya harus ditafsirkan atau dimaknakan dalam pemakaian bahasa. Diantara pembicara dan pendengar pun terdapat unsur yang kadang-kadang tidak menampak dalam ujaran. Ujaran yang berbunyi, "Saya marah, Saudara!" terlalu banyak perlu dipersoalkan; misalnya, mengapa ia memarahi saya; apakah karena tidak meminjami uang lalu ia memarahi saya? Dan apakah akibat kemarahan itu? Kelihatannya tidak mudah mendeskripsikan semantik. Untunglah hal yang dideskripsikan masih berada di dalam ruang lingkup jangkauan manusia.

\section{Klasifikasi Makna}

Makna dapat diklasifikasikan atas beberapa kemungkinan sebagai mana diuraikan berikut ini.

1. Makna Leksikal dan Makna Gramatikal Makna leksikal adalah makna leksikon/lek- sen atau kata yang berdiri sendiri, tidak berada dalam konteks, atau terlepas dari konteks. Ada yang mengatakan bahwa makna leksikal adalah yang terdapat dalam kamus. Makna leksikal merupakan makna yang diakui ada dalam leksem atau leksikon tanpa leksikon itu digunakan. Begitu kata amplop dapat diberi makna "sampul surat", dengan tanpa menggunakan kata itu dalam konteks. Maka makna "sampul surat" yang terkandung dalam kata amplop itu merupakan makna leksikal. Makna gramatikal merupakan makna yang timbul karena peristiwa gramatikal. Makna gramatikal itu dikenali dalam kaitannya dengan unsur yang lain dalam satuan gramatikal. Jika satuan yang lain itu merupakan konteks, makna gramatikal itu disebut juga makna kontekstual. Dalam konteks itu, kata amplop, misalnya, tidak lagi bermakna "sampul surat", tetapi dapat berarti uang suap. Makna gramatikal tidak hanya berlaku bagi kata atau unsur leksikal, tetapi juga morfem. Makna gramatikal juga dapat berupa hubungan semantis antar unsur.

\section{Makna Denotatif dan Makna Konotatif}

Makna denotatif merupakan makna dasar suatu kata atau satuan bahasa yang bebas dari nilai rasa. Makna konotatif adalah makna kata atau satuan lingual yang merupakan makna tambahan, yang berupa nilai rasa. Nilai rasa itu bisa bersifat positif, bersifat negatif, bersifat halus, atau bersifat kasar. Dua buah kata atau lebih memiliki makna denotatif yang sama. Perbedaannya terletak pada makna konotatifnya. Kata kamu dan anda, misalnya, memiliki makna denotatif yang sama, yakni "orang kedua tunggal". Kedua kata itu berbeda makna konotatifnya . Kata kamu berkonotasi "kasar", kecuali bagi orang-orang Tapanuli/Batak, dan kata anda berkonotasi halus. Demikian juga kata dia dan beliau. Kedua kata 
itu berdenotasi "orang ketiga tunggal", tetapi kata dia tidak berkonotasi "hormat", sedangkan kata beliau berkonotasi "hormat".

Dengan kata lain, kata beliau bermakna konotasi "positif", sedangkan kata dia tidak berkonotasi "positif". Karena tidak berkonotasi "negatif", kata dia dapat ditafsirkan berkonotasi "netral" (periksa Chaer: 1990). Nilai positif dan negatif yang menjadi ukuran nilai rasa, dapat dinyatakan dengan berbagai cara. Hormat dan tidak hormat menggambarkan nilai rasa. Sopan dan tidak sopan juga menggambarkan nilai rasa.

\section{Makna Lugas dan Makna Kias}

Makna lugas merupakan makna yang sebenarnya. Makna lugas disebut juga makna langsung, makna yang belum menyimpang atau belum mengalami penyimpangan. Sebaliknya, makna kias adalah makna yang sudah menyimpang dalam bentuk ada pengiasan hal atau benda yang dimaksudkan penutur dengan hal atau benda yang sebenarnya. Sebuah kata dapat digunakan secara lugas dan dapat pula digunakan secara kias. Dengan kata lain, sebuah kata dapat memiliki makna lugas dan memiliki makna kias. Kedua kemungkinan itu tergantung pada penggunaannya. Makna kias timbul karena ada hubungan kemiripan atau persamaan. Orang yang pendek disebut cebol, wanita nakal disebut kupu-kupu malam. Kadang-kadang, hubungan itu ditampakkan dalam isi dan wadah, seperti amplop yang berarti "uang suap".

\section{Makna Luas dan Makna Sempit}

Dilihat dari segi cakupan atau tingkat keluasan makna dua buah kata, makna dapat dibedakan menjadi dua kategori, yakni makna luas dan makna sempit. Makna luas merupakan akibat perkembangan makna suatu tanda bahasa.
Contoh klasik yang paling populer dalam studi semantik bahasa Indonesia adalah kata saudara, yang tidak hanya bermakna "saudara satu bapak/ibu", tetapi juga "orang lain yang tidak ada hubungan darah.". Makna kitab "buku" merupakan makna sempit. Kitab yang berarti "buku" itu tidak lagi "sembarang buku”. Sekarang kata kitab lebih bermakna "buku suci" seperti yang tampak dalam pemakaian kitab Al-Qur'an, kitab Injil, kitab Zabur dan seterusnya.

Pada tahun 1960-an kata kitab itu masih memiliki makna yang tidak hanya terbatas pada kitab suci, tetapi juga kitab-kitab yang lain (buku). Dalam kehidupan sehari-hari sering kita dengar juga ungkapan "dalam arti luas" atau "dalam arti sempit", seperti yang dapat dikenakan pada kata taqwa. Kata taqwa itu dalam arti luas adalah "berserah diri kepada Allah" dan dalam arti sempit adalah "menjalankan segala perintah Allah dan menjauhi segala larangan-larangan-Nya".

Dengan demikian, makna luas dan makna sempit itu tidak hanya karena perubahan makna, tetapi juga karena tingkat cakupan makna yang sudah terkotak menjadi dua, yakni makna luas dan makna sempit.

\section{B. METODE PENELITIAN}

Penelitian ini adalah tentang penggunaan bahasa dalam kehidupan sehari hari yang menggunakan metode kualitatif dengan pendekatan deskriptif. Metode ini bertujuan untuk menganalisis penggunaan leksikon "lum" pada penamaan suku "lum" dalam tataran semantik pragmatik pada bahasa Bangka khususnya dialek Belinyu Kota.

\section{B.1 DATA PENELITIAN}

Data penelitian berupa kalimat - kalimat dalam percakapan sehari-hari pada bahasa Bangka 
Dialek Belinyu Kota yang menggunakan leksikon "lum" maupun respon terhadap suatu kalimat tanya yang menggunakan leksikon tersebut.

\section{B.2. PROSEDUR PENELITIAN}

Data dikumpulkan dengan menggunakan teknik simak catat lapangan. Catatan lapangan yang dimaksud dalam penelitian ini terdiri atas catatan lapangan secara deskriptif dan catatan lapangan tentang segala sesuatu yang terjadi dalam data sebagaimana adanya yang dapat diamati.

\section{B.3. TEKNIK PENYAJIAN DATA}

Data disajikan dalam deskripsi lingual penggunaan leksikon adverbia "lum" dalam percakapan sehari -hari. Selanjutnya leksikon tersebut dianalisis secara semantik pragmatik untuk menemukan bentuk dan makna asli leksikon "lum" dan memaparkan asal usul penggunaan leksikon tersebut pada suatu kelompok masyarakat (suku lum). Bahasa yang dipilih adalah bahasa Bangka dialek Belinyu Kota dengan alasan bahwa penggunaan leksikon "lum" yang merujuk pada masyarakat dinamisme tersebut berawal dari bahasa Bangka dialek Belinyu kota yang digunakan oleh masyarakat Belinyu kota.

\section{PEMBAHASAN DAN HASIL PENELI- TIAN}

\section{1.MAKNA LEKSIKAL " $L U M$ "}

Lum adalah salah satu leksikon yang bermakna negasi pada bahasa Bangka yang dapat diterjemahkan sebagai leksikon "belum" dalam bahasa Indonesia. Pada bahasa Bangka Bagian Utara, varian leksikon lum ada dua, yakni lum dan lom. Lum umumnya digunakan oleh masyarakat yang tinggal disekitar atau di dalam kota Belinyu sedangkan lom biasanya digunakan oleh masyarakat yang tinggal di kota Belinyu (bahasa Belinyu kota), terutama masyarakat Sungai Ke- ladi, yang memiliki varian aksen bahasa Bangka Dialek Belinyu.

Leksikon "lum" dalam kajian kelas kata dikategorikan sebagai kelas adverbia yang digunakan dalam kalimat negasi untuk menunjukan perasaan atau sikap pada suatu hal yang masih dalam keadaan tidak. Penggunaan leksikon tersebut dapat dipaparkan pada contoh kalimat bahasa Bangka Dialek Belinyu Kota berikut ini :

Kalimat Pernyataan:

$\begin{array}{ccccr}\text { a. Nyo } & \text { ge } & \overrightarrow{\text { lum }} & \text { pegi } & \text { aben. } \\ \text { Dia } & \text { juga } & \text { belum } & \text { pergi } & \text { artikel* }\end{array}$

$\begin{array}{cccc}\text { b. Kamek } & \text { lum } & \text { tau } & \text { kisa } \\ \text { kami } & \text { belum } & \text { tahu } & \text { cerita }\end{array}$

Kalimat tanya:

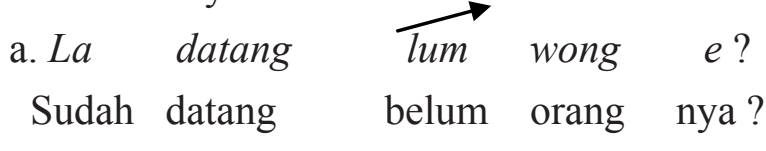

\section{b. lum.}

Belum.

Dari contoh - contoh kalimat tersebut dapat dilihat bahwa leksikon "lum" selalu digunakan dalam kalimat sebelum verba, dan jika leksikon tersebut berdiri sendiri, seperti pada contoh respon kalimat tanya, maka leksikon "lum" menunjukan makna denotatif untuk menunjukan suatu keadaan yang masih tidak.

Secara pragmatik, penggunaan leksikon adverbia "lum" dapat digunakan untuk berbagai tujuan seperti tujuan emotif, tujuan honorofik (kesantunan berbahasa) serta tujuan sebenarnya (denotatif). tujuan - tujuan tersebut tentu saja berhubungan dengan intonasi sehingga menghasilkan makna yang dapat dipahami oleh penutur dan lawan tutur. Tujuan -tujuan tersebut dapat dipaparkan melalui contoh berikut ini : 


\section{A.1 Tujuan emotif}

a. lum apola

gawe

Belum

$$
\text { ada pekerjaan }
$$

nyo.

nya

Kalimat tersebut menekankan adverbia "lum" diawal kalimat (kalimat negasi) dengan intonasi naik dan diikuti predikat "ado" datar menunjukan makna "lum" sebagai tujuan emotif, artinya menekankan suatu keadaan yang masih tidak. Intonasi awal yang tinggi, dalam bahasa Bangka Dialek Belinyu Kota, menunjukan bahwa leksikon tersebut digunakan untuk tujuan emotif yang bermakna konotasi, sebaliknya untuk tujuan emotif yang bermakna denotatif selalu menggunakan intonasi mendatar ataupun intonasi naik yang berayun memanjang.

Leksikon "lum" dapat pula berdiri sendiri sebagai bentuk respon dari suatu kalimat tanya dengan intonasi naik, contoh :

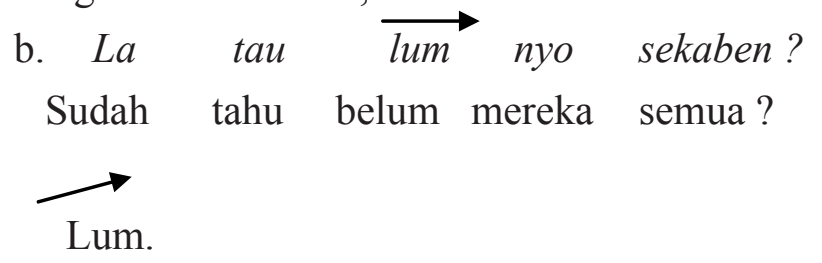

Belum.

Respon "lum" yang berdiri sendiri tanpa ada tambahan kata ataupun frasa penjelas dan dituturkan dengan intonasi naik, menunjukan suatu keadaan yang masih tidak yang bermakna konotatif negatif, artinya, ketika lawan tutur didalam memberikan respon menaikan intonasi, maka hal tersebut bermakna konotatif negatif.

Dari pemaparan contoh contoh diatas dapat diketahui bahwa intonasi naik pada penggunaan adverbia "lum" baik dalam suatu rangkaian kalimat maupun berdiri sendiri menunjukan makna yang konotatif dan persepsi yang negatif pula.

\section{A. 2 Tujuan honorifik (kesantunan)}

a.nyo bedua ge $\overrightarrow{l u m}$ kemano-kemano. Mereka berdua juga belum kemana-mana.

Kalimat diatas menggunakan adverbia "lum" dengan intonasi datar yang diawali oleh adverbia "ge" yang naik (penekanan), menunjukan suatu keadaan pada subjek dengan makna negatif tetapi menggunakan bentuk bahasa yang santun, artinya keadaan subjek tersebut masih dapat diterima berdasarkan sosiokultural lingkungan masyarakat setempat.

\section{A. 3 Tujuan informatif \\ a. la pegi lum wong tu? sudah pergi belum orang itu?

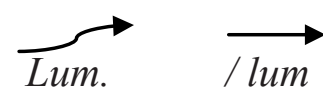

Belum

Leksikon "lum" diungkapkan dalam bentuk intonasi datar dalam kalimat tanya. Seperti pada penggunaan "lum" dalam tujuan honorifik, makna lum diatas bukanlah berupa kesantunan berbahasa, akan tetapi suatu respon yang wajar terhadap suatu keadaan yang masih tidak, dengan kata kata lain, "lum" dalam tujuan informatif ini memberikan pada makna yang berbeda, tergantung intonasi yang digunakan. Makna informatif dapat merujuk pada makna sebenarnya (denotatif) maupun makna yang bersifat negatif. Penggunaan leksikon "lum" yang bertujuan informatif dalam respon dituturkan dalam bentuk intonasi yang datar, tentu saja memberikan suatu informasi yang masih dalam keadaan tidak yang sebenarnya (denotatif) sedangkan respon yang berintonasi bergelombang seperti contoh diatas biasanya digunakan untuk memaparkan dan menjelaskan suatu keadaan yang masih tidak ataupun untuk memberikan deskripsi atau gambaran suatu hal yang tidak sesuai harapan. 


\section{D.2. Penamaan "Ium" pada Orang Mapur}

Banyak spekulasi mengenai asal usul kelompok masyarakat dinamisme, sebagian berpendapat bahwa mereka adalah Orang Mapur yang hidup dan tinggal menyebar di wilayah kecamatan Belinyu. Ciri khas dari orang orang tersebut adalah bahwa mereka masih belum menerima satu dari enam agama resmi di Indonesia. Kelompok masyarakat tersebut menolak beragama secara praktis, bahkan beberapa tetua, menolak memeluk agama walau hanya secara identitas. Keadaan tersebut tentu saja menjadi ciri khas mereka dengan sebutan "wong lum" atau "urang lum" dalam hal ini berarti orang yang belum memeluk agama. Keadaan tersebut merupakan faktor utama yang menjadi penyebab penggunaan leksikon "lum", seperti yang dipaparkan diatas, sebagai penamaan untuk suku mereka.

Secara semantik pragmatik, penggunaan nama tersebut bermakna konotasi negatif. Hal tersebut dikarenakan leksikon "lum" adalah adverbia negasi (negatif) untuk mengungkapkan atau menuturkan suatu keadaan yang masih tidak. Penggunaan leksikon "lum" yang berdiri sendiri lazim digunakan oleh masyarakat Belinyu kota dalam memberikan respon. Awalnya, penggunaan "lum" adalah bentuk respon dari sebuah pertanyaan yang diajukan oleh masyarakat Belinyu Kota mengenai keadaan keyakinan orang Mapur tersebut apakah telah memeluk agama atau belum.

Dialog tersebut dapat dideskripsikan seperti berikut ini:

\begin{tabular}{lrccc}
\multicolumn{3}{r}{ Pertanyaan } & \multicolumn{1}{c}{} \\
La & islam & lum & wong & tu? \\
Sudah & islam & belum & orang & itu?
\end{tabular}

Respon

Lum.

belum
Dikarenakan respon yang selalu diberikan adalah "lum" dengan nada bergelombang naik panjang pada setiap pertanyaan yang sama mengenai "status keyakinan" mereka itulah merupakan awal penyebutan atau penamaan orang Mapur dengan sebutan suku lum. Pemberian nama tersebut sudah berlangsung sejak lama dan turun temurun, tetapi penggunaan leksikon lum untuk menunjukan keadaan orang orang tersebut hanya lazim digunakan oleh masyarakat Belinyu kota tetapi kurang lazim digunakan oleh masyarakat lain yang masih kerabat dengan mereka seperti masyarakat suku Panji (desa Riding Panjang, Desa Gunung Muda dan Dusun Tanjung Batu, Desa Lumut).

Fakta dilapangan adalah penamaan lum apalagi menyebutkan mereka dengan istilah "suku lum" masih belum dapat diterima oleh kelompok masyarakat dinamisme tersebut baik orang mapur, orang air abik maupun orang pejem. Hal tersebut seperti yang telah dipaparkan diatas, penamaan "lum" adalah suatu bentuk ungkapan yang bernada informasi negatif sehingga penamaan tersebut tentu saja bertujuan emotif informatif, artinya leksikon tersebut dipakai untuk memberikan informasi kepada masyarakat lain serta menekankan keadaan mereka yang masih tidak memeluk agama. Di dalam tataran semantik, penamaan menggunakan adverbia negasi pada kelompok masyarakat tersebut dikarenakan ada yang yang ditandai (saussure: 1967) yaitu keadaan mereka yang belum atau "lum" memeluk salah satu agama resmi di Indonesia. Secara pragmatik, penggunaan leksikon "lum" adalah penggambaran mengenai keadaan mereka yang masih belum (beragama). Oleh karena itu, penamaan "lum" pada kelompok masyarakat tersebut digunakan untuk membedakan antara masyarakat yang telah dan belum beragama. Secara semantik pragmatik, penamaan tersebut 
dapat juga bernuansa ejekan atau cemoohan.

\section{F. KESIMPULAN}

Dari hasil pemaparan diatas dapat disimpulkan bahwa awal mula penamaan "lum" pada masyarakat dinamisme seperti orang pejem, orang air abik dan orang mapur adalah karena keadaan mereka yang masih tidak memeluk salah satu agama resmi di Indonesia. Penamaan tersebut menimbulkan ketersinggungan jika diungkapkan secara langsung kepada kelompok -kelompok masyarakat tersebut.

Secara semantik makna leksikal "lum" adalah suatu keadaan yang masih tidak atau setara dengan leksikal "belum" dalam bahasa Indonesia (KBBI: 2012) sedangkan secara pragmatik, leksikal tersebut memberikan makna ejekan atau cemoohan oleh karena itu penamaan lum pada mereka dengan menyebutkan "suku lum" adalah bentuk ejekan yang tidak disadari sehingga penggunaan leksikal tersebut harus dihindari, selain itu, kelompok masyarakat tersebut tidak menerima penamaan "lum" pada mereka.

Masyarakat dinamisme yang tinggal di wilayah Bangka bagian Utara biasanya dipanggil berdasarkan tempat tinggal mereka, masyarakat yang tinggal di wilayah mapur dipanggil orang mapur (urang mapor), masyarakat yang tinggal di wilayah air abik dipanggil orang air abik ( urang $a i$ $a b e c$ ) dan yang tinggal diwilayah pejem disebut orang pejem (urang pejem). Penamaan lum pada kelompok - kelompok masyarakat tersebut hanyalah sebuah ungkapan atau gelar yang bermakna ejekan atau sindiran.

Masih tidak dapat dipastikan apakah kelompok masyarakat tersebut merupakan bagian dari suku sekak atau bukan, mengingat kelompok masyarakat Panji (suku Panji) juga memiliki bahasa (perbedaan pada aksen), adat istiadat serta keyakinan yang sama dengan mereka, hanya saja, nilai -nilai agama modern (islam) telah diterima dengan baik oleh masyarakat suku Panji dari pada kelompok-kelompok masyarakat dinamisme tersebut. 


\section{Daftar Pustaka}

Aarts,J.M.G and J.P Calbert. 1979. Metaphor and Non-metaphor. The semantics of adjective and noun combinations. Tubingen : Niemeyer

Anderson, John M. 2007. The Grammar of Proper Names. Oxford: Oxford University Press.

Almos, Rona et.al. 2009. Makna nama diri pada masyarakat Minangkabau. Padang : Universitas Andalas Press

Bach.K. 2002. Giorgione was So-Called Because of His Name,' Philosophical Perspectives. Oxford: Oxford University press

Chaer, Abdul. 1990. Pengantar Semantik Bahasa Indonesia. Jakarta: Penerbit Rineka Cipta

Crystal, David. 1987. The Cambridge encyclopedia of language. (2nd edition.) Cambridge: Cambridge University Press.

Danesi, Marcel. 2004. Messages, Signs, and Meaning. Ottawa: Canadian Scholar`s Press

De Saussure, Ferdinand. 1967. Cours de linguistique générale. Edition critique. Paris: ed. \& comm. Tullio de Mauro

Departemen Pendidikan Nasional. 2012. Kamus Besar Bahasa Indonesia. Jakarta: Pusat Bahasa

Jendra, I Wayan. 2000.”Bahasa dalam Dinamika Sosial Perspektif Sosiolinguistik (PokokPokok Pikiran)". Makalah yang Dipresentasikan pada Acara Matrikulasi Mahasiswa S-2 Linguistik Tahun 2005 Universitas Udayana, Denpasar.

Levinson, Stephen C. 1983. Pragmatics. Cambridge: Cambridge University Press.

Mulyana, Deddy. 2005. Ilmu Komunikasi Suatu Pengantar. Bandung : Remaja Rosdakarya

Palmer, F.R..1981. Semantics. London : Cambredge University Press

Parker, Frank. 1986. Linguistics for Non-Linguists. London: Taylor \& Francis. Ltd
Quirk, Randolph et al.1985. A Comprehensive Grammar of the English Language. London: Longman

Subroto, Edi. 2007. Pengantar Metode Penelitian Linguistik Struktural. Surakarta: UPT Penerbitan dan Pencetakan UNS (UNS Press).

Verhaar, J.W.M. 1977. Pengantar Linguistik. Yogyakarta: Gadjah Mada University Press 